\title{
THE OPEN ECONOMY: JUSTICE FRANKFURTER AND THE POSITION OF THE JUDICIARY
}

\author{
ERNEST J, BROWH $\dagger$
}

\begin{abstract}
"I do not think the United States would conte to an end if we lost our power to declare an Act of Congress void. I do think the Union would be imperiled if we could not make that declaration as to the laws of the several States. For one in wy place sees how often a local policy prevails with those who are not trained to national viezes and how often action is taken that embodies what the Consmerce Clause was meant to end."
\end{abstract}

-Holdes, Law and the Court, in Collected Legal Papers 291, 295-96 (1920).

That Justice Frankfurter's first Supreme Court opinion should be one holding a state statute unconstitutional seemed at the time an amusing irony, easy and inevitable though the Court's unanimous decision appeared to be. ${ }^{1}$ That subsequent opinions and votes indicated a large and generalized tolerance of state legislation, whatever the source or nature of the challenge, seemed entirely in character for one who had often invoked the classic statements of James Bradley Thayer or Justice Holmes and urged restraint and hesitance as the appropriate attitude of a constitutional judge. ${ }^{2}$ That in later years Justice Frankfurter should not infrequently find merit in claims of conflict between state legislation and the commerce clause, even while he maintained a limiting view of the proper scope of judicial activity, ${ }^{3}$ has to some seemed paradox.

But paradox abounds, for those who seek it, in the institutions of American constitutional law. That a government democratic in base and representative in method should have what are thought to be its shaping and fundamental decisions made by the majority of a small group of men appointed for life is paradox enough. That the questions requiring those decisions should be presented in the haphazard of litigation, either wholly private or private in instigation or defense, and by lawyers chosen fortuitously and often without reference to special competence, is even greater paradox.

Paradox, however, is only seeming contradiction. If it presents the intersecting thrusts of ideas each of which enjoys acceptance, it shares that attribute with the controversies which take place in every active field of the law, and perhaps particularly in constitutional law. ${ }^{4}$ As with those controversies, resolu-

†Professor of Law, Harvard Law School.

1. Hale v. Bimco Trading, Inc., 306 U.S. 375 (1939).

2. E.g., Cloverleaf Butter Co. v. Patterson, 315 U.S. 148, 177 (1942) (dissenting opinion); Wisconsin v. J. C. Penney Co., 311 U.S. 435 (1940); Minersville School Dist. v. Gobitis, 310 U.S. 586 (1940) ; Osborn v. Ozlin, 310 U.S. 53 (1940).

3. Frankfurter, John Marshall and the Judicial Function, 69 HARv. L. REv. 217, 234-38 (1955), reprinted in FRANkFuRTER, OF LAW AND MEN 3, 24-30 (1956).

4. Cf. Frankfurter, Some Observations on the Nature of the Judicial Process of Supreme Court Litigation, 98 Proceedings, Amierican Philosophicar Soctety 233, 239 (1954), reprinted in Frankfurter, OF LAW AND MEN 31, 43 (1956). 
tion requires accommodation and adjustment rather than extrapolation of doctrine. The paradoxes involved in permitting individuals, without official sanction and often in the face of official displeasure, to invoke the assurances of the Constitution, and the paradoxes in seeking, within institutions largely flexible, a measure of stability of structure and values through review by judges whose detachment fulfills their function, if not all of their desirable qualifications, have, as might have been expected, produced their doctrinal responses. Under such heads as "standing," "ripeness," "case or controversy" and "judicial restraint," these responses have in the aggregate presented the problem of the judicial function which has been the overriding concern of Justice Frankfurter both on and off the bench. It should be remembered, however, that these are doctrines of adjustment and accommodation. It seems unlikely that internal rigidity would serve their purpose.

That restraint and hesitance to interpose a constitutional veto should in many. or even most, instances be the appropriate judicial attitude does not necessarily mean that the occasions should be undifferentiated. James Bradley Thayer would apparently have recognized little or no difference, whether the Court was considering the scope of federal powers or a state statute challenged under the commerce clause as hostile to the federal system. ${ }^{5}$ Quite apart from abstract ideas of the coequality of the several branches of the federal government, Herbert Wechsler has demonstrated why the structure of our government should make judges particularly hesitant to hold federal legislation beyond the scope of the powers granted to the central government. ${ }^{6}$ Without attempting present decision of the matter, one may ask whether the constitutional negatives upon the national government's action do not involve different considerations and hence make appropriate somewhat different methods and standards of adjustment. Justice Brandeis urged a broad tolerance of state legislation against a claim that its substance went beyond the fluid standards of that process which is "due"; he pointed out that, within the isolated chambers of the states, the risks from legislation proving harmful were limited, while the lessons of benefit or of harm could be learned universally. ${ }^{7}$ Justice Holmes must inevitably have agreed with these sentiments had he still been a member of the Court. ${ }^{8}$ Yet almost twenty years before, in the words which introduce this paper, he had acknowledged one of the lessons of judicial experience-when the limits that the federal system imposes upon its components are in question, when the centrifugal, isolating or hostile forces of localism are manifested in state legislation, the interests of union require that these factors be recognized and the judicial negative be interposed. It was hardly necessary to add what some of the Jus-

5. Thayer, The Origin and Scope of the American Doctrine of Constitutional Law, 7 Harv. L. Rev. 129 (1893); 2 Thayer, Cases on Constitutional Law 2190 (1895).

6. Wechsler, The Political Safeguards of Federalism: The Role of the States in the Composition and Selection of the National Government, 54 CoLUM. L. Rev. 543, 559 (1954), reprinted in Federalism Mature aNd EMIERGent 97, 109 (Macmahon ed. 1955).

7. New State Ice Co. v. Liebmann, 285 U.S. 262, 306-11 (1932) (dissenting opinion).

8. See Truax v. Corrigan, 257 U.S. 312, 344 (1921) (dissenting opinion). 
tice's successors have not always recognized-the Court might the more readily intervene against state legislation under a commerce clause challenge, since it would at most make what it believed a proper allocation of power, tentative and subject to reallocation by Congress; a negative in the name of substantive due process was, however, presumably universal and final. Justice Holmes's observation is the more significant since he was not notably sensitive to the presence of an excessive localism. ${ }^{9}$ In this area at least, experience must have found him a somewhat reluctant pupil.

Twenty years and more ago, the then Professor Frankfurter wrote of "one of the greatest duties of a judge, the duty not to enlarge his authority."10 Acknowledging the preponderant truth of this observation, one may speculate that the Justice's experience in the intervening years has contributed to the definition of the authority, and of the duty. At the same time, he went on to say:

"For a court to hold that decision does not belong to it, is merely to recognize that a problem calls for the exercise of initiative and experimentation possessed only by political processes, and should not be subjected to the confined procedure of a lawsuit and the uncreative resources of judicial review."11

Written in a discussion of state legislation and the commerce clause, these words were echoed from the bench in a jointly signed opinion only a few years later:

"Judicial control of national commerce-unlike legislative regulationsmust from inherent limitations of the judicial process treat the subject by the hit-and-miss method of deciding single local controversies upon evidence and information limited by the narrow rules of litigation. Spasmodic and unrelated instances of litigation cannot afford an adequate basis for the creation of integrated national rules which alone can afford that full protection for interstate commerce intended by the Constitution. We would, therefore, leave the questions raised by the Arkansas tax for consideration of Congress ...."12

These are brave words. But no Justice since Chief Justice Taney, the joint authors included, has consistently followed their implications. For Chancellor Kent of New York, the commerce clause afforded no judicially discoverable negative upon state statutes other than conflicting federal legislation. ${ }^{13}$ James Bradley Thayer approved this position. ${ }^{14}$ And it perhaps approximated the opinion of Chief Justice Taney, though even he concurred in the heavily qualify-

9. Cf. Pennsylvania v. West Virginia, 262 U.S. 553,600 (1923) (dissenting opinion); Western Union Tel. Co. v. Kansas ext rel. Coleman, 216 U.S. 1, 52 (1910) (dissenting opinion).

10. Frankfurter, The Conmerce Clause under Marshall, Taney and Waite 80 (1937) (hereinafter cited as The Commerce Clause).

11. Id. at 96 .

12. Black, Frankfurter and Douglas, JJ., dissenting in McCarroll v. Dixie Greyhound Lines, Inc., 309 U.S. 176, 188-89 (1940).

13. See Livingston v. Van Ingen, 9 Johns. R. 507, 572-80 (N.Y. 1812).

14. 2 Thayer, Cases on Constituttonal Law 2190 (1895). 
ing opinion of Justice Curtis in Cooley v. Board of Port Wardens. ${ }^{15}$ If Justice Frankfurter brought this attitude or understanding to the Court, the enlightenment afforded by judicial experience had clearly modified it by the time of his concurring opinion in Carter $v$. Virginia ${ }^{16}$ and his concurrence with the majority opinion in Southern Pac. Co. v. Arizona. ${ }^{17}$ His dissent in Capitol Greyhound Lines $v$. Brice completes the change in emphasis and approach:

"Once more we are called upon to subject a State tax on interstate motor traffic to the scrutiny which the Commerce Clause requires so that interstate commerce may enjoy freedom from State taxation outside of those narrow limits within which States are free to burden such commerce."1s

Had the views of Kent and Thayer prevailed, one cannot say that our system would have been unworkable. But the very mechanisms of our government, or perhaps the lack of them, would have multiplied frictions and strains which we have been spared. These mechanisms do not give to Congress any regularized opportunity or duty of reviewing, to test for compatibility with the federal system, state statutes even in their skeletal form as enacted, much less as fleshed by application, interpretation and administration. Nor has Congress been so idle that such matters could be assured a place on its agenda without competition from other business which might often be deemed more pressing; in Justice Jackson's phrase, the inertia of government would be heavily on the side of the centrifugal forces of localism. ${ }^{19}$ Moreover, as Paul Freund has suggested, it is perhaps as well that members of Congress have not been given the additional task of corralling, by quid pro quo or otherwise, votes and support on behalf of their constituencies for or against specific local legislation. ${ }^{20}$ Nor do the largely unsuccessful attempts of judges and commentators to formulate rules applicable in the field of commerce suggest that Congress could by legislation in generalized terms give in advance adequate or satisfactory guidance to the courts.

From at least the Cooley decision onward, the Justices, some of them more and some of them less frequently, have found occasions where the implications from the commerce clause unaided by legislation have seemed to them to warrant interposing a negative against state legislation. They have usually been the result of an appraisal more carefully particularized than legislation could afford and, one feels, than many opinions have disclosed. These occasions have at times been such as to produce helpful congressional reaction. ${ }^{21}$ But the occasions are not to be found specified in the Constitution. Justices may talk, often with vigor and not infrequently in dissent, of judicial legislation, even of trying statutes, and of the fact that the Constitution authorizes Congress, not the

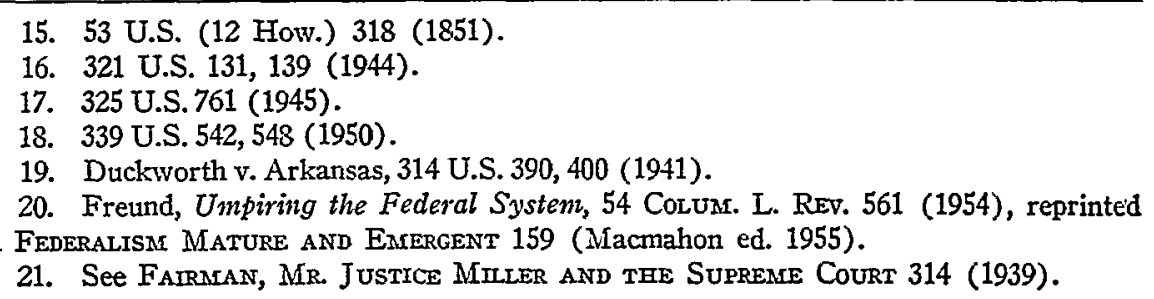


Court, to regulate commerce. But this is not the line of division. Division arises in deciding whether the Court.should intervene in a particular instance, not whether it should ever do so. And decision has found few generalized guides. As explicit constitutional and legislative guides have been absent, judicially made or discovered formulations have been inadequate. Differences in appraisal, and sharp ones, have arisen. But on the whole, these differences seem to have been less important than differences in perception. Although the impression is not susceptible of proof, the decisions seem adequate, and even wise, to the extent that the particular interests at stake, long-range as well as short, have been perceived and understood.

\section{State Taxation and the Comarerce Clause: A Conceptual Problem}

For the past twenty-five years, it has been the frequently and officially proclaimed policy of the government of the United States that barriers to international trade should be lowered, and that efforts to that end should be constant and unremitting. Not without hesitation, vacillation and some backsliding, it has followed this policy by legislation, agreement and treaty. With some measure of success, it has urged the benefits of such a policy upon its friends and allies, particularly in Western Europe. There has been interested, and perhaps other, opposition on occasion, but these policies have received a remarkable nearunanimity of support from academic and detached opinion in the United States.

Quite in contrast has been academic legal opinion when state taxes have been challenged in the Supreme Court as barriers to trade within the United States. Whether state taxes were challenged under the rubric of jurisdiction to tax, or of the commerce clause, this body of opinion has with remarkable concert supported decisions upholding them and has questioned those decisions limiting their incidence. ${ }^{22}$

This divergence of opinion may be explained in several ways. It may be that the challenges to internal taxes have been largely groundless, weighed on any rational scale. Some apparently believe this, but it seems open to doubt, and should be investigated. Or it may be that legal commentators would be nationalist and protectionist if they were considering international trade, and but follow the same bent in internal matters. There is little evidence that this is true, and it seems improbable. Not only is there clear awareness of our historic commitment to a certain degree of freedom of internal trade and movement, but there is general acceptance of the condemnation of state statutes which are clearly and

22. See, e.g., Barrett, "Substance" vs. "Form" in the Application of the Commerce Clause to State Taxation, 101 U. PA. L. REv. 740 (1953), and Barrett, State Taxation of Interstate Conmerce, 4 VAND. L. REv. 496 (1951) ; Bittker, The Taxation of Ont-of-State Tangible Property, 56 Y ALE L.J. 640 (1947); Dunham, Gross Receipts Taxes on Interstate Transactions, 47 Colun. L. REv. 211 (1947); Hartman, Sales Taxation in Interstate Connerce, 9 VANd. L. Rev. 138 (1956); Hellerstein \& Hennefeld, State Taxation in a National Economy, 54 HARv. L. REv. 949 (1941) ; Lockhart, State Tax Barriers to Interstate Trade, 53 HaRv. L. Rev. 1253 (1940), and Lockhart, The Sales Tax in Interstate Commerce, 52 HaRv. L. Rev. 617 (1939). 
indisputably preferential. ${ }^{23} \mathrm{~A}$ third possibility is that it is adhesion to the doctrinal purity of the Kent-Thayer tradition which has produced disapproval of those instances when the Court has held state tax legislation inoperative. But this doctrinal purity would be heavily compromised by the decisions which are accepted; yielding to pragmatic considerations not rarely, doctrinal purity when invoked can be only a makeweight. As a final possibility, the identity of the litigants may have had some influence in inducing approval or disapproval of decisions. There is more than one hint, in both judicial writing and that of commentators, that in a contest between the state (should one say "any state"?) and commercial enterprise-usually corporate commercial enterprise-the claims of the latter start with the handicap of a less worthy motive and purpose. Of course, to permit such coloration of opinion is to overlook the fact that in the international field, mutatis mutandis, it is the same commercial enterprise, the same corporate commercial enterprise, which carries on the functions of transportation and distribution and must, at least in first impact, disburse for tariffs, tolls and taxes. It is one of the perhaps unfortunate concomitants of our case system of constitutional controversy that the identity of the immediate litigant, rather than the ultimate interests involved, may color opinion concerning the decision-that cause and champion may be unnecessarily identified. In his lectures on the commerce clause, Professor Frankfurter pointed out:

"The checkered fortunes in the conflict between national and state powers, as resolved by the Supreme Court, are partly due to the fact that the respective claims have not come before the Court in their full amplitude, but have been entangled in specific controversies arousing the emotions and allegiances of the moment."24

More recently Justice Frankfurter has had occasion to remind us, "it is true of this principle, as of others, that the principle is not to be reduced to the appeal of the particular instance in which it is invoked."25

Whatever the reason for this body of opinion, it appears to have achieved a substantial consensus, even though there are difficulties in detailed formulation and application. This consensus, very generally stated, is that to safeguard our internal open market, we must protect interstate commerce against discriminatory taxation, but that is the extent of our concern with state taxes. It is recognized that "discrimination" and "discriminatory" are not self-defining terms, and that they are not to be limited to legislation which is patently hostile to the nonlocal. Rather, it is acknowledged that in its competition with local business, the interstate is not to be disadvantaged because it is interstate, that "it shall not be burdened with cumulative exactions which are not similarly laid on local business."26 To achieve this end, we consider "multiple burdens," we employ

23. See, e.g., Welton v. Missouri, 91 U.S. 275 (1875).

24. The Conarerce Clause 23.

25. Panhandle Eastern Pipe Line Co. v. Michigan Pub. Serv. Comm'n, 341 U.S. 329, 340 (1951).

26. Western Live Stock v. Bureau of Revenue, 303 U.S. 250, 258 (1938). 
"apportionment," and similar devices. "Interstate commerce must pay its way" -this states the goal and the judgment. ${ }^{27}$ Discrimination, intentional or fortuitous, is bad, but equality is its own justification, and is all we need seek. By such a formulation, we eliminate the unmerited and privileged position which interstate commerce enjoyed under the older conceptions that "interstate commerce cannot be taxed at all," or "interstate commerce may not be taxed directly." 28 Such is the thrust of what was clearly intended by Justice Stone as a definitive review and restatement in Western Live Stock v. Bureau of Revenue. ${ }^{29}$ Perhaps the most comprehensive brief statement of the position is that of Justice Rutledge, concurring in Memphis Natural Gas Co.v. Stone:

"[I]t is enough for me to sustain the tax imposed in this case that it is one clearly within the state's power to lay insofar as any limitation of due process or 'jurisdiction to tax' in that sense is concerned; it is nondiscriminatory, that is, places no greater burden upon interstate commerce than the state places upon competing intrastate commerce of like character; is duly apportioned, that is, does not undertake to tax any interstate activities carried on outside the state's borders; and cannot be repeated by any other state."30

Even first-stage analysis should be enough to show that this consensus, this formulation, is inadequate to perceive and to appraise the interests involved in the impact and operation of some of our more common taxes. Whatever their intrinsic merit and inevitable appeal, equality and egalitarianism are not the passwords to solution of the problems of maintaining an open economy in a federal system. Starting with a great reluctance to question state taxes, more often than not limiting himself to an inquiry whether jurisdiction to tax existed and apparently feeling that that was the extent of his duty and authority, Justice Frankfurter has perceived, presumably from experience on the Court, that policies wise abroad may not be without wisdom internally, and that constitutional imperatives may be discovered to support at least some of them.

Certainly in his first years on the Supreme Court, Justice Frankfurter would have found no broader grounds for restraints upon state taxing power than those implied by Justice Rutledge. Concurring in State Tax Comm'n v. Aldrich, he wrote:

"The taxing power of the States was limited by the Constitution and the original ten amendments in only three respects: (1) no State can, without the consent of Congress, lay any imposts or duties on imports or exports, except as necessary for executing its inspection laws, Art. I, $\S 10$ [2]; (2) no State can, without the consent of Congress, lay any tonnage duties, Art. I, $\S 10$ [3]; and (3) by virtue of the Commerce Clause, Art. I, $\S \&$ [3], no State can tax so as to discriminate against interstate commerce."

27. See id. at 254-55.

28. Ibid.

29. 303 U.S. 250 (1938).

30. 335 U.S. $80,96-97$ (1948). See also Interstate Oil Pipe Line Co. v. Stone, 337 U.S. 662, 666-67 (1949).

31. 316 U.S. 174,182 (1942). 
In indicating that discriminatory taxes were so clearly self-classifying as to warrant grouping them with, and in the lonely company of, those taxes explicitly prohibited by the Constitution, the Justice was consistent with the view expressed earlier in his commerce clause lectures, where he had indicated surprise that in Brown v. Maryland ${ }^{32}$ Chief Justice Marshall had not based his decision invalidating the tax upon the fact that it was discriminatory against foreign commerce. ${ }^{33}$

But to a generation less empirically minded than our own, discrimination was not so inherently the basis of classification explicit or implicit in the Constitution. It was apparently not a quirk of the Marshall mentality, nor a tactic in the long-range constitutional strategy sometimes attributed to him, that led the Chief Justice not to dwell upon discrimination in Brozon v. Maryland any more than he had in $M c C u l l o c h v$. Maryland, ${ }^{34}$ where it might have been equally relevant. If we look to the report of argument there is no evidence that counsel stressed the discriminatory nature of the tax as particularly significant. Somewhat to the contrary, Meredith and Wirt argued that if these general license laws, as they termed them, were upheld, then Maryland might "establish a tariff of discriminating duties for herself, and affect, if not defeat, the commercial policy of the country."35 But the discrimination with which they were concerned was not against foreign, and in favor of domestic, goods. Rather it was among foreign nations "in direct repugnancy to the policy of the Union."38

If it is important that we see the historical record aright, then it should be noted that Marshall at least gave the appearance of being prepared to uphold a tax despite its discriminatory effect against foreign commerce. The statutory provision specifically at issue in Brown v. Maryland was an amendment exacting a license fee of "importers of foreign articles . . . and other persons selling the same by wholesale."37 This amendment was held unconstitutional. The statute to which it had been added imposed a license fee upon retailers, but, in its first section, defined "retailer," so far as here relevant, as one "engaged in the selling of any goods, wares and merchandise, except such as are the growth, produce and manufacture of the United States." 38 This was as discriminatory as the license tax on importers selling at wholesale, yet Marshall's indication that the area of constitutional protection extended only to the first sale, and while goods were in the original package, clearly appears to have contemplated that the retailer would have been required to pay the fee, discriminatory against imported goods, from which the wholesaler was constitutionally exempted. Nor could Marshall have been unaware of this possibility, for Justice Thompson's

\footnotetext{
32. 25 U.S. (12 Wheat.) 266 (1827).

33. The Commerce Clause 37.

34. 17 U.S. (4 Wheat.) 159 (1819).

35. 25 U.S. (12 Wheat.) at 269.

36. Id. at 276 .

37. Maryland Laws 1821, c. 246.

38. Maryland Laws 1819, c. 184.
} 
dissent charged the majority with making a meaningless differentiation between wholesalers and retailers. ${ }^{39}$ To this point, Marshall made no effective answer.

This slight excursion into history is, it should be clear, not designed to adduce controlling authority to uphold state taxes discriminatory against, and hostile to, foreign or interstate commerce. It is designed only to buttress a thesis which should require but slight support, the conclusion that decisions condemning such statutes were by no means inevitable-that they were products of judicial responsibility, and were arrived at by a process which warrants similar assumptions of responsibility when the interests involved and the actions taken are of comparable significance. When Justice Field came to write the opinion in Welton $v$. Missouri, rejecting the possibility which Marshall had apparently contemplated, ${ }^{40}$ he found the task not a simple one, if we may judge by the product. The result seems inevitable if we may apply the standard of the clear needs of a sound federal system, but stating it in terms of explicit constitutional imperatives is another matter.

\section{Judicial Responsibility: Pragmatic Drfficulties}

Having spent possibly unnecessary time and words in indicating that what we may call antidiscrimination decisions in the commerce field were not inevitable, let us turn to consider why they may not be adequate. For that is the lesson which Justice Frankfurter appears to have learned; or perhaps, one should say, to have sensed. For it is true that the opinions do not yield a rich harvest of evaluative explanation-though they are seldom more sparse in that respect than the opinions in opposition. However, statements such as those in Freeman $v$. Hewit that the tax is unconstitutional because "a direct tax on commerce" have worthy precedent even if not the merit of self-illumination. ${ }^{41}$ Alexander Bickel has recently pointed out that Justice Brandeis customarily contented himself with this formulation rather than going more deeply, at least in explicit terms, into the factors possibly involved in decision. ${ }^{42}$ And there is the constant reminder of that discerning Justice's somewhat surprising remark, which must appear particularly perverse to those for whom discrimination or its absence is the sole and controlling standard, "the imposition would have been void, not because it resulted in discrimination, but because the fee would be a direct burden on interstate commerce." 43

Let us go, if we may, somewhat beyond direct burdens and consider the interests involved in a few of the taxes with which the Supreme Court has concerned itself in recent years. There is room for difference of opinion concerning trade policy, external and internal, but confidence in decisions is inspired only by a belief first in the Court's awareness, and then in its appraisal, of the

39. 25 U.S. (12 Wheat.) at 288.

40. 91 U.S. 275 (1875).

41. 329 U.S. 249 (1946).

42. Bickel, The Unpublished Opinions of Mr. Justice Brandeis 115-18 (1957).

43. State Bd. of Equalization v. Young's Market Co., 299 U.S. 59, 62 (1936). 
interests involved. A tariff policy legislatively determined solely or largely in terms of its effects, beneficial or burdensome, upon the mercantile group who distribute goods, would seem singularly myopic. There seems little reason why adequately conceived judicial action in analogous situations should not also take into account interests beyond the immediate. Occasions arise when an unwillingness to attribute to the Supreme Court something akin to whimsical perverseness leads one to conclude that it did not understand even the immediate operation of a decision; ;4 at other times, verbal formulae of questionable relevance seem to have obscured what a little arithmetic would have cleared up. ${ }^{45}$ Fortunately these occasions are relatively rare. But it is also rare, unfortunately, that the Court gives evidence of having gone, even in its thought, beyond abstractions and shibboleths such as "apportionment," "direct burdens," "multiple burdens," "discrimination," and "interstate commerce must pay its way." Such symbols and slogans may serve as rallying points, but they offer not a great deal in either understanding or guidance. Without pretending to any great capacity for economic analysis, one can still go slightly further.

\section{State Taxation of Interstate Transportation}

Let us look first at a tax on transportation, or the proceeds therefrom, so far as it applies to interstate or foreign commerce. There has been division of opinion concerning apportioned taxes on transportation within recent years. The flat statement has been made that a state tax on interstate transportation, apportioned to transportation within the state, is unobjectionable. ${ }^{46}$ Certainly such a tax demonstrates no apparent discrimination or hostility against interstate commerce, and apportionment introduces the egalitarian appeal of "contributing its due" which to some not only requires but even permits no answer. Is the only objection the abstract one that the tax is "directly on commerce"?

It is of course true that a tax apportioned to the segment of a journey within the taxing jurisdiction is less burdensome, in many ways less objectionable than a tax computed on the distance or the proceeds of the whole journey. But does this necessarily clear the skirts of the apportioned tax? One need not go back to the castles on the Rhine and the Loire, to the hazards and burdens of the overland routes to the Far East, in order to measure the power and ascertain the position of the tolltaker on a strategic trade route. ${ }^{47}$ Our own preconstitutional history discloses that the ports and the states astride the trade routes exploited their situation to the disadvantage and displeasure of their less strategically situated neighbors, and that recriminations and reprisals resulted. On more than one occasion, The Federalist refers to this unhappy situation and holds out the promise that the proposed Constitution will end it. ${ }^{48}$ Madison described the situation as graphically as any when he wrote:

44. See, e.g., Illinois Cent. R.R. v. Minnesota, 309 U.S. 157 (1940).

45. See, e.g., International Harvester Co. v. Evatt, 329 U.S. 416 (1947).

46. See Canton R.R. v. Rogan, 340 U.S. 511, 515-16 (1951).

47. Cf. Condemffe, The Comarerce of Nations chapters I-V (1950).

48. E.g., The Federalist Nos. VII, at 37-38 (Hamilton), XXII, at 131-32 (Hamilton), XXXIII, at 202 (Hamilton), and XLI, at 267-68 (Madison) (Modern Library ed. 1937). 
"The other source of dissatisfaction was the peculiar situation of some of the States, which having no convenient ports for foreign commerce, were subject to be taxed by their neighbors, thro' whose ports, their commerce was carried on. New Jersey placed between Phila \& N. York, was likened to a cask tapped at both ends; And N. Carolina, between Virg ${ }^{a} \&$ S. Carolina to a patient bleeding at both Arms."49

Marshall, not uninformed of the circumstances leading to the adoption of the Constitution, closes his opinion in Brozen $v$. Maryland by invoking, had the result been otherwise, what he apparently assumes to be the clearly impermissible possibility of state taxes on the transit of goods passing through the jurisdiction..$^{50}$ For these purposes it matters not whether the exaction is a tariff or toll on the entrance of goods, or a tax on transportation. In fact, if a port area is involved, the tax on transportation may well lie more heavily upon consumers in the hinterland, who depend upon transit through and beyond the port. The tariff or toll on entrance will fall upon the people of the port area as well as those beyond, and this may well exert a moderating influence in its imposition. But the tax on transportation falls only on those in remoter areas beyond the port and, accordingly, may tend to rise to the level of what the traffic will bear.

History need hardly be invoked. As through traffic equals, exceeds or predominates over local in any jurisdiction-port, passage, city, county or statea tax on transport, apportioned with whatever show of fairness one desires, can clearly be imposed at diminishing relative cost to the local taxpayers and voters. Outsiders with no voice in the determination of the tax will bear an increasingly large share of the burden. This is a cheap and domestically attractive way to finance a government, where opportunity offers. Not coincidence, but geography produced a series of such taxes in Pennsylvania in the nineteenth century and led to the clearest judicial statement concerning them, Justice Miller's opinion concurring in the Case of the State Freight Tax ${ }^{51}$ and dissenting from the result in State Tax on Railway Gross Receipts. ${ }^{52}$ Justice Jackson also developed these considerations in his concurrence in Northwest Airlines, Inc. v. Minnesota, where, as it happened, they were of limited relevance $;^{53}$ and Justice Reed made brief allusion to them in Joseph $v$. Carter \& Weekes Stevedoring Co.54 One wonders whether apportionment, no matter what its appeal to the abstraction of equality, could carry the day today if a thinly populated state such as Arizona, sitting astride the main transportation routes to and from southern California, adopted a tax on transportation, or the proceeds therefrom, occurring in the state. Or, if Westchester County in New York, or Brooke and Ohio Counties in West Virginia, or any of a number of well-positioned cities, counties or states followed suit, could the federal system tolerate

\footnotetext{
49. 2 Madison, Writings 395 (Hunt ed. 1901).

50. 25 U.S. (12 Wheat.) at 28485.

51. \&2 U.S. (15 Wall.) 232 (1873).

52. 82 U.S. (15 Wall.) 284, 297 (1873).

53. 322 U.S. 292,307 (1944).

54. 330 U.S. $422,433-34$ (1947).
} 
one of its component units thus exploiting its geographical position? The history of the struggles for unimpeded access to ports, navigable streams and trade routes does not suggest an affirmative answer. If the Court is nevertheless prepared to sanction such taxes, the decision would be cast in more reassuring form if, in addition to invoking the ideals of local fiscal autonomy and the somewhat disembodied equalism of apportionment, it acknowledged that it was consciously giving warrant to the taxing jurisdiction to exploit its geographical position at the cost of consumers and producers outside.

The Supreme Court has struck down not only the Pennsylvania taxes already mentioned, ${ }^{55}$ but also the apportioned taxes on transportation in Galveston, $H$. \& S.A. Ry. v. Teras ${ }^{56}$ and in Joseph v. Carter \& Weekes Stevedoring Co. Justice Frankfurter was in the condemning majority in the latter decision, and he joined with Justice Jackson in expressing grave and what appear to be soundly based doubts concerning the decisions in Canton R.R. v. Ragan ${ }^{\mathrm{br}}$ and Western $M d . R y . v$. Rogan. ${ }^{58}$ These latter recent decisions appear to be among the few which have tolerated such taxes. Maine $v$. Grand Trunk Ry. ${ }^{\text {jo }}$ often summoned as support for the apportioned gross receipts $\operatorname{tax}^{60}$ is, of course, with its near contemporary, Horn Silver Mining Co. v. New York, ${ }^{\text {o1 }}$ the product of Justice Field's specious syllogism to the effect that since a state could exclude a foreign corporation from doing local business, it could without raising constitutional issues exact any price it chose for permission. When that simple approach to the problem of the limits on states in a federal system was abandoned in Western Union Tel. Co. v. Kansas and succeeding decisions, Grand Trunk lost any authority it had. ${ }^{62}$ It had never been a decision dealing with the merits of a tax on transportation, but only a decision-later repudiated - that the Court would not look to the merits.

Justice Frankfurter's chief connection with the matter of transportation taxes occurred in Central Greyhound Lines, Inc. v. Mealey; ;3 $^{63}$ the subsequent application of this decision well illustrates the hazards in transference of formulations. ${ }^{64}$ The case has subsequently been cited as authority for the idea that a

55. State Tax on Railway Gross Receipts was effectively overruled in Philadelphia \& So. S.S. Co. v. Pennsylvania, 122 U.S. 326 (1887).

56. 210 U.S. 217 (1908). That the tax was apportioned is clear from the statute, Texas Gen. Laws 1905, c. 141, $\$ 1$. Justice Holmes apparently attributed no particular significance to this, since his opinion did not mention it.

57. 340 U.S. $511,516(1951)$.

58. 340 U.S. 520,522 (1951).

59. 142 U.S. 217 (1891).

60. See, e.g., Rutledge, J., in Interstate Oil Pipe Line Co. v. Stone, 337 U.S. 662, 666 (1949).

61. 143 U.S. 305 (1892).

62. Western Union Tel. Co. v. Kansas ex rel. Coleman, 216 U.S. 1 (1910). Cf. Henderson, The Position of Foreign Corporations in Amertcan Constitutional Law chapters VI-VIII (1918).

63. 334 U.S. 653 (1948).

64. Cf. Frankfurter, J., dissenting in Braniff Airways, Inc. v. Nebraska State Bd. of Equalization, 347 U.S. 590, 603 (1954): "One of the most treacherous tendencies in legal 
state may impose an apportioned tax on interstate transportation, or on its proceeds..$^{\text {ar }}$ Indeed, the decision did uphold a New York tax on gross receipts from certain interstate bus transportation, if apportioned to the part of the journey taking place in New York. But let the emphasis fall upon the word "certain." The transportation in question was between the New York City area and the Rochester-Buffalo area of western New York. Instead of remaining always within the state by proceeding northward to Albany, then turning west, the bus company took the then more advantageous route which cut across northern New Jersey and northeastern Pennsylvania. New York did not attempt to collect a tax on the proceeds of transportation originating in the state and going to a destination outside. It did attempt to tax this traffic from New York City to Rochester or Buffalo.

Justice Frankfurter, writing for the majority, held that New York might tax but required the state to remit that part of the tax appropriate to the fraction of the journey taking place in New Jersey and Pennsylvania. The Justice seems unquestionably right in ruling that the travel was in interstate commerce. However, the result cannot be generalized or extended without caution. If, as appears the case, the hazard from even apportioned transportation taxes is that of exploiting geographic position at the cost of the outsider, the hazard does not exist if New York is allowed to tax traffic beginning and ending within the state. Therefore, no reason appears to deprive New York of the power to tax; nor can any reasoned basis be suggested for applying this conclusion to a tax on interstate transportation in other geographic contexts.

One aspect of the decision is troubling, however. In requiring New York to remit the tax on that fraction of the fare which corresponded to the fraction of mileage in New Jersey and Pennsylvania, Justice Frankfurter appeared to contemplate that those states might demand a tax on fare attributable to their mileage. But their standing to levy a transportation tax would be objectionable, precisely as New York's was not. For a jurisdictional purist, the fact that some of the transportation took place outside New York might be enough to diminish New York's claim; perhaps this alone was implied. So restricted, the decision lends no support to the general application of apportioned taxes to receipts from interstate transportation.

Let us pursue one aspect of the decision a step further. It has been said that for a jurisdictional purist the fact that some transportation took place outside New York would be enough to justify diminution of the New York tax. But if jurisdictional concepts within a federal system are, like commerce concepts, to be shaped for the appropriate or better ordering of the relations of the component units, ${ }^{66}$ then, once assured that commerce considerations would prevent New Jersey and Pennsylvania from taxing at all, the holder of this more prag-

reasoning is the transfer of generalizations developed for one set of situations to seemingly analogous, yet essentially very different, situations."

65. See Canton R.R. v. Rogan, 340 U.S. 511, 516 (1951).

66. Cf. Skiriotes v. Florida, 313 U.S. 69 (1941). 
matic concept of jurisdiction might find little reason to deny to New York a tax on the entire fare, even though he might have not the slightest temptation to join in Justice Murphy's dissenting opinion.

A somewhat different tax, though still involving transportation, evoked a major dissent from Justice Frankfurter, and marked clearly his turn away from the early and acquiescent dissent in McCarroll v. Dirie Greyhound Lines, Inc. ${ }^{67}$ Capitol Greyhound Lines v. Brice involved a Maryland statute which exacted from the owner of any vehicle operated as a common carrier a tax of two per cent of the value of the vehicle before it could be used on the state's highways. ${ }^{68}$ The tax was sustained by a majority of the Court which recited the ancient learning that a state may require, even from purely interstate operators, a fair price for the use of the highways which it constructs and maintains. Major bus lines operating interstate had challenged the tax. To one with a rudimentary familiarity with the geography of the Atlantic seaboard and with even the most generalized knowledge of the character and volume of the through north-south traffic necessarily using a few miles of Maryland's highwaysmatters certainly not beyond the confines of judicial knowledge, or noticereference to a fair price, thus computed, for use of the highways is indeed the incantation of an empty formula. A reading of Justice Frankfurter's dissent will recall the legislative hobbles upon rail traffic ${ }^{69}$ - stopping all trains at every county seat, and the like ${ }^{70}$ - which the Court for years tolerated until the demand for, and the demands of, an efficient rail transportation system were perceived. That the states build and maintain highways-in part-and that they should be allowed a price for use can be granted without viewing Capitol Greyhound and other present-day versions of Grand Trunk and Horn Silver as embodiments of greater wisdom or understanding than the originals. Perhaps -though the issues as abstractly stated appear unrelated-Castle v. Hayes Freight Lines, Inc., more recently decided, offers a promise that, with Justice Frankfurter, the Court has come to have a somewhat greater perception of the significance of a nationwide system of highway transportation. ${ }^{71}$

Economically and politically analogous to transportation taxes exploiting geographical position are taxes on extraction or processing of materials where the taxing jurisdiction approaches a monopoly position and consumption is largely outside the state. The unfortunate potentialities are obvious, yet it has proved difficult to discover mechanisms for classification or workable criteria for judgment which will tend to separate cases calling for condemnation from those where a tax should clearly be sustained. This difficulty may explain why even such a clear exploitation as the Pennsylvania tax on processing anthracite

67. 309 U.S. 176, 183 (1940).

68. 339 U.S. $542(1950)$.

69. Id. at 548 .

70. See Powet, Vagaries and Varieties in Constiputional Interpretation 177 78 (1956). See also cases collected in the opinion of Justice Reed in Morgan v. Virginia, 328 U.S. $373,378-79$ nn. $16 \& 17$ (1946).

71. 348 U.S. 61 (1954). 
coal was allowed to go unchecked. ${ }^{72}$ Recently however, the Court was astute to find that a Texas tax on gathering gas had its stated incidence on the process of transportation and was therefore-the conclusion was unanimously deemed to follow-unconstitutional. ${ }^{73}$ The Justices who made up the majority in Canton R.R. v. Rogan but three years before do not explain the constitutional dichotomy that makes a tax on a process not separate from interstate transportation invalid in Texas and a tax on the proceeds from interstate (or even foreign) transportation valid in Maryland.

\section{Sales and Compensating Use Taxes}

Sales and compensating use taxes upon goods ordered from outside the taxing state, and sales taxes upon those being shipped outside, have produced a tortuous pattern of decision since Gregg Dyeing Co. v. Query provided an effective breach in what had been thought a constitutional barrier. ${ }^{74}$ As the injured and indignant quality of his dissent in McGoldrick $v$. Berwind-White Coal Mining Co. indicated, ${ }^{75}$ Chief Justice Hughes could hardly have recognized the implications and significance of his yielding to the blandishments of the appeal of equality which was implicit in Gregg Dyeing, and which Justice Cardozo made completely explicit in Henneford $v$. Silas Mason Co. ${ }^{76}$

The barrier breached in the name of equality in Gregg Dyeing appeared for a time to have been completely leveled in Berwind-White. Indeed, equality itself appeared to have been the victim as well as the panache of this great victory, and interstate transactions once immune from tax seemed to have become disadvantageously subject to multiple taxes. But the Court soon found a spokesman in Justice Rutledge and at least a majority who would protect equality as well as use it as a rallying point against constitutional immunity for interstate sales. Thus far, no sales or compensating use taxes have been approved when their impact would have placed the interstate seller at competitive disadvantage with the local seller. After the comments and analysis of Thomas Reed Powell, among others, the separate decisions need hardly be traced or analyzed. ${ }^{77}$

Why should these simple transactions and simple transaction taxes present

72. Heisler v. Thomas Colliery Co., 260 U.S. 245 (1922). The analogous situation in the field of price regulation is obvious in Cities Serv. Gas Co. v. Peerless Oil \& Gas Co., 340 U.S. 179 (1950). As domestic consumption increases and the competitive position changes, this shades off to a situation like that in Milk Control Bd. v. Eisenberg Farm Products, 306 U.S. 346 (1939), which in abstract or formal terms may be the same, but which presents no comparable challenge to a federal system. But cf. Shafer v. Farmers Grain Co., 268 U.S. 189 (1925) ; Lemke v. Farmers Grain Co., 258 U.S. 50 (1922).

73. Michigan-Wisconsin Pipe Line Co. v. Calvert, 347 U.S. 157 (1954).

74. 286 U.S. 472 (1932).

75. 309 U.S. 33, 59 (1940).

76. 300 U.S. 577 (1937).

77. See Powell, New Light on Gross Receipts Taxes-The Berwind-White Case, 53 Harv. L. Rev. 909 (1940); Powell, Note, Sales and Use Taxes: Collection from Absentee Vendors, 57 Harv. L. Rev. 1086 (1944) ; Powell, More Ado about Gross Receipts Taxes, 60 Harv. L. REv. 501, 710 (1947). 
a continuing problem? Is it not enough to have removed the interstate sale from the privileged position of immunity, to have been adequately alert to prevent the interstate transaction from being taxed more frequently or heavily than its local competition, and to have wisely made a competitive market the more likely by choosing to accept the tax of the buyer's rather than the seller's state? Is more involved? Are there other interests to be evaluated? The answer appears to be that there well may be more, that evaluation is difficult and that decision should certainly be made with some hesitation, and with consciousness of its implications.

The issue is a simply stated yet difficult issue of protectionism. Should one state in a federal system be able to raise its price levels, isolate itself and protect its markets from the outside price competition thereby stimulated? Or does the federal system demand at least that degree of economic unity which would require that consumers and buyers within the state have some measure of access to a free market outside?

The issue is considered explicitly in Baldwin v. Seelig, ${ }^{78}$ and only there is it explicitly dealt with, so far as I know. New York had by legislation raised the minimum price of milk at all levels from farmer to consumer. The Court held that the state could not, in its effort to protect its farmers from the outside price competition thereby generated, prohibit the resale of milk more cheaply purchased. The classic statement is Justice Cardozo's :

"The Constitution was framed under the dominion of a political philosophy less parochial in range. It was framed upon the theory that the peoples of the several states must sink or swim together, and that in the long run prosperity and salvation are in union and not division."70

When the State of Washington enacted a sales tax, and then sought to prevent movement of buyers to outside markets by the device of the compensating use tax, it was meeting the same problem which New York had faced and was dealing with it in similar manner. The opinion upholding the Washington statute and looking away from Baldwin v. Seelig was assigned to Justice Cardozo. T. R. Powell has remarked that "his skill was adequate for the task, or nearly so." 80 This is a nice turn of ironical phrase, but inaccurate measurement. The opinion in Henneford $v$. Silas Mason Co. is not one of the ornaments of the Justice's judicial career. Baldzein v. Seelig remains undifferentiated by the observation that there New York sought to project its legislation within the borders of another state. It did so to the same extent, and only to the same extent, that a Kansas statute establishing a maximum alcoholic content for beverages seeks to project itself into the brewing state of Missouri or the distilling state of Kentucky, or that the Washington statute projected itself outwards. A few differences can be found between the New York milk statute and the Washington tax statute; their weight to turn the scale is another ques-

78. Baldwin v. G. A. F. Seelig, Inc., 294 U.S. 511 (1935).

79. Id. at 523 .

80. Powell, Vagaries and Varieties in Constitutional Interpretation 190 (1956). 
tion. New York established a rigid prohibition against the sale of cheap milk and smothered all price competition. The sales and compensating use tax permit previously existing price competition to continue, but, equally with the New York legislation, they stifle the enhancement or creation of price competition which would otherwise take place as a result of the local sales tax. Since normally no price competition arises between farmers in the sale of milk, this difference-the fact that New York did not allow existing price competition to continue-may not be as significant as its statement may suggest. Both New York and Washington were willing to continue the competitive status quo ante, but raised to a higher price level. The question remains whether a single state should be allowed to alter its domestic price level in isolation, unaffected by the presence of its neighbors.

The issue of protection-not preference, but protection ${ }^{81}$ - is the issue which pervades our sales and use tax problems. This issue was recognized, and recognized more freely than it has been here, in the difficult tax adjustments which were required to initiate the European Coal and Steel Community. As we have done, the experts of the Community realized that in choosing between the application- of excise taxes of a buyer's state and those of a seller's state, competitive markets could better be maintained by permitting the incidence of the taxes of the former. As we have failed to do, at least explicitly, the Community's experts have been troubled to recognize that comprehensive application of the buying state's excise taxes could create sectors of national protection within the Community. 82

The problem confronting the Court has been whether to require that some avenue to a competitive free market outside the taxing jurisdiction be available to buyers. For a time, from Henneford $v$. Mason through McGoldrick v. Berwind-IWhite and Nelson r'. Sears, Roebuck \& Co., ${ }^{83}$ the triumph of local protection seemed complete. More recently, Norton Co. v. Department of Reve$u u c^{84}$ and Miller Bros. Co. v. Maryland ${ }^{85}$ in combination appear to provide a reasonably workable access to free markets, though one appreciably more restricted than was assumed to exist at the time of Sonneborn Bros. v. Cureton. ${ }^{\mathrm{s6}}$

81. The idea that protection is usually a mask for preference, and that any tariff almost inevitably becomes preferential may be so widely accepted as to give some justification for Justice Frankfurter's remark: "A tariff barrier between States, moreover, presupposes a purpose to prefer those who are within the barrier . . ." H. P. Hood \& Sons, Inc. v. DuMond, 336 U.S. 525, 570 (1949). But this is hardly inevitable. Condliffe states that the Tariff of 1861 was imposed to countervail the competitive effect of high excise taxes imposed internally to raise revenue. Condiffre, The Comarerce of Natrons 229 (1950). The conclusion is certainly possible, and despite Henneford, the compensating use tax has both this purpose and effect.

82. See Mendershausen, First Tests of the Schtman Plan, 35 Rev. Econ. \& STAT. 269, 27S-82 (1953).

83. 312 U.S. 359 (1941).

84. 340 U.S. 534 (1951).

85. 347 U.S. 340 (1954).

86. 262 U.S. 506 (1923). 
Divisions and changes in the Court, however, do not assure stability for those decisions.

There seems little tendency to question Baldwin v. Seelig in its specific context. The sales and use tax decisions do produce sharp divisions. The fact that both present the issue of protection does not necessarily mean that they must be undifferentiated. Protection of a rigid price structure imposed by legislation may or may not involve difficulties and strains quite different from those resulting from protection of the elevation of a fluid price structure, raised by the imposition of a comprehensive sales or gross receipts tax. ${ }^{87}$ Competence to answer that question is not professed here. In so far as meaningful classification can be made, the Court in the past appears to have acted generally from the premise that economic interdependence was the basic requirement of the federal system, however much single states might be permitted to adopt and enforce individualized standards of health and safety legislation. Perhaps the degree of economic segmentation accomplished by successfully protected sales and use taxes at various levels can be tolerated, but the decision is not one involving only the simple invocation of equality of tax treatment. Equality is the question, not the answer.

In the succession of sales and use tax cases, Justice Franlfurter has played a significant part. His opinion for a divided Court in McLeod v. J. E. Dilworth $C o .^{88}$ marked the first limitation on what had appeared to be the broad scope of $M c$ Goldrick $v$. Berwind-White. While the Justice addressed himself to the problem of Arkansas's power to impose its sales tax largely in terms of jurisdiction, as then appeared his custom, and while one may agree with Justice Rutledge that purely jurisdictional considerations did not furnish compelling reasons for denying Arkansas its tax, still another factor made its brief but foreshadowing appearance in the opinion: "The very purpose of the Commerce Clause was to create an area of free trade among the several States." 80 The technique of making a search for jurisdiction and, that found, regarding the task as ended, was strongly enough ingrained at the time, however, to produce the contemporaneous opinion in General Trading Co. v. State Tax Comm'n, affording what, on any other grounds, had at least the appearance of anomaly. ${ }^{90}$

The opinion in Freeman $v$. Hewit ${ }^{91}$ marked the fuller development and application of the idea briefly stated in McLeod $v$. Dilworth. If the statement that a direct tax on interstate commerce is prohibited reveals neither the limits of its applicability nor the values which it serves, it does convey the idea that economic unity of the nation may require more of the states than abstention from the hostile and discriminatory. While it does not delineate the edges which

87. But cf. Viner, International Trade and Economic DevelopMent 102 (1952), suggesting that compensating duties may be justified if extensive internal direct controls result in a highly artificial price structure.

88. 322 U.S. 327 (1944).

89. Id. at 330 .

90. 322 U.S. 335 (1944).

91. 329 U.S. 249 (1946). 
will place accurately all transactions, it does suggest that the exemption of the cleanly multistate transaction, be it transportation or sale, from state transaction taxes serves purposes which have expressed the primary values of the federal system. Freeman v. Hewit was eloquent in its appeal to those values. If few Justices since Justice Bradley have attempted to explain their operation and significance, the reason may be that in an age of specialization the task is thought to lie in the province of the economic analyst.

Freeman v. Hewit is the latest of Justice Frankfurter's opinions in the sales and use tax field. But his significant presence in the majority in Norton Co. v. Department of Revenue and his necessary presence in the majority in Miller Bros. v. Maryland indicate with adequate clarity that the idea emerging and briefly stated in McLeod $v$. Dilworth has since become of increasing significance to him.

\section{State Property, Income and Inheritance Taxation}

The problems arising from the multiple incidence of state property, income and inheritance taxes are of such iridescent nature that perhaps brief reference should not even be attempted. One starts with the awareness that the due process clause of the Fifth Amendment imposes no geographical limits upon the taxing power of the United States. ${ }^{92}$ If the due process clause of the Fourteenth Amendment does impose such limits upon the states, they can hardly derive from verbal imperative. Rather, the concept of jurisdictional limitation is employed, as is the commerce clause, for the better and more appropriate ordering of the federal system. In the absence of congressional definition of jurisdictional concepts and legislative enforcement, the restraints which have emerged bear the stamp of judicial responsibility.

A few years ago Professor Bittker argued from the then recent decisions allowing multiple incidence of state inheritance taxes upon intangibles that the same result should follow with respect to real estate and tangible chattels. ${ }^{93}$ In Trcichler v. Wisconsin, the Court refused to follow this line of thought. ${ }^{94}$ While one may question the direction of the movement which Professor Bittker recommended, his arguments against differentiation between tangibles and intangibles seem eminently sound. Convenience or ease of formulation may raise differences, but somewhat simplistic thought is required to find it either inevitable or imperative that land and fixed chattels be taxed in but one state, that property taxes on moving rolling stock be apportioned and that intangible property and income may be taxed in several jurisdictions.

What considerations, if any, should call for the judges to devise not sporadic but generally conceived limitations which may minimize multiple impact of state property, inheritance and income taxes? Here again the issue is more than

92. Cook v. Tait, 265 U.S. 47 (1924); United States v. Bennett, 232 U.S. 299 (1914).

93. Bittker, The Taxation of Out-of-State Tangible Property, 56 YALE L.J. 640 (1947).

94. 338 U.S. 251 (1949). 
avoidance of a competitive disadvantage in local markets for moving or nonlocal capital. ${ }^{95}$ The broader consideration is whether we should seek to preserve or accelerate the mobility of capital.

In a period when great intellectual effort is being devoted to the part which capital formation and availability plays in economic growth, ${ }^{96}$ when the United States by a long series of income and estate tax treaties is seeking to increase the mobility of capital throughout the friendly world ${ }^{97}$ it appears appropriate that some thought be given to the need for mobility of capital within the United States, and the effect of tax deterrents. ${ }^{98} \mathrm{We}$ can judge only tendencies; but, other things being equal, an investor will tend to keep his capital at home, where its yield will be subject to diminution by only one tax, if placing it elsewhere will diminish a comparable yield by two. Perhaps the need for capital mobility within the country is not great, although the even distribution of development necessary to support this idea seems lacking. Perhaps other hazards to investment make state tax burdens, softened by the impact of the federal income tax, relatively unimportant. A more probable conclusion is that lawyers, through multiple incorporation and related devices which take advantage of the existence of states limiting taxation to encourage business, have been able to surmount or neutralize barriers with which the judges have remained unconcerned.

The one situation in which economic considerations have clearly required judicial action has been in the incidence of property taxation on carriers' equipment. A nationwide transportation system sends heavy and expensive equipment into and through many states. If each state in which it appeared could tax the whole value of that equipment, there would be a strong tendency to a series of local or, at best, regional transportation systems disjointed by the absence of equipment interchanges. To meet the need for a larger system it was possible either to localize taxing power in a single state, or to apportion value and taxing power among many. For a time we followed the first alternative with respect to the equipment of carriers by water and the second with respect to carriers by rail. ${ }^{99}$ More recently, the Supreme Court has indicated that the constitutional imperative is the overriding one, rather than the collection of

95. Intangible capital may be placed at a competitive disadvantage after Curry v. McCanless, 307 U.S. 357 (1939), and State Tax Comm'n v. Aldrich, 316 U.S. 174 (1942).

96. See, e.g., Lewis, The Theory of Economic Growtr (1955); The Dynamic Society, Times Literary Supplement (London), Feb. 24, 1956, p. 109.

97. See Kanter, The United States Income Tax Treaty Program, 7 NAT'L TAx J. 69 (1954).

98. Cf. Bruins, Einaudi, Seligman \& Stantp, Report on Double Taxation (League of Nations 1923) ; Report and Resolutions of Technical Experss, Double Taxation and TAX Evasion (League of Nations 1925); Bloch \& Heilemann, International Tax Relations, 55 YALE L.J. 1158 (1946).

99. See 61 HaRv. L. Rev. 1464 (1948); see also Powell, Note, Northwest Airlines v. Minnesota: State Taxation of Airplanes-Herein Also of Ships and Sealing Wax and Railroad Cars, 57 HARv. L. REv. 1097 (1944). 
specifics, by shifting the treatment of carriers by water-at least on inland water routes-to accord with that given carriers by rail.100

While the taxation of the equipment of rail and water carriers still followed different patterns, Northwest Airlines, Inc. v. Minnesota presented the question of Minnesota's power to tax the full value of the flight equipment of an interstate and international airline incorporated in that state and having its principal business headquarters there. ${ }^{101}$ Assimilating the situation to that of a water carrier would have made upholding Minnesota's tax a simple task under decisions then prevailing. Justice Frankfurter's opinion upholding the Minnesota tax hardly furnished guides indicating whether other states could tax as well; apparently, a majority could concur only if the implications of decision were left unclear. Later, in allowing a state through which an airline operated to impose an apportioned tax on flight equipment, athe Court has appeared to modify heavily, if not to overrule, the Northwest Airlines decision, and to assimilate taxation of air carriers' equipment to the pattern which now prevails for both rail and water carriers. ${ }^{102}$

\section{Conclusion}

Justice Frankfurter's dissent from the more recent decision illuminates the development of his thought. He did not deny, of course, that the state had jurisdiction to tax. But no single system for apportionment existed. Several methods, each of which individually imposed no unfair burden on commerce, but all of which varied markedly, had been developed. The Justice therefore foresaw "the diverse and fluctuating exercise of power by the various States, even where based on concededly relevant factors, which imposes an undue burden on interstate commerce." 103 The themes of this dissent had been sounded before-over sixty years earlier. They are to be found in the dissent of Justice Bradley in Pullman's Palace Car Co. v. Pennsylvania. ${ }^{104}$ As was usual with Justice Bradley, his understanding and his prevision were clear, his fears not unjustified by subsequently developing facts.

Justice Holmes and Justice Brandeis have clearly and avowedly been the predecessors to whom Justice Frankfurter has most frequently looked for wisdom to shape his own thought. His experience has brought his understanding of the economic assumptions of the federal system into growing parallel with that of Justice Bradley, a fitting member of any trio of judicial guides.

100. Standard Oil Co. v. Peck, 342 U.S. 382 (1952); Ott v. Mississippi Barge Line Co., 336 U.S. 169 (1949).

101. 322 U.S. 292 (1944).

102. Braniff Airways, Inc. v. Nebraska State Bd. of Equalization, 347 U.S. 590 (1954).

103. Id. at 605-06.

104. 141 U.S. $18,33-34$ (1891). 